DOI: https://doi.org/10.47233/jteksis.v1i2.53

\title{
SISTEM PAKAR DIAGNOSA PENYAKIT KANKER MULUT PADA MANUSIA DENGAN METODE FORWARD CHAINING MENGGUNAKAN BAHASA PEMROGRAMAN VISUAL BASIC 2017
}

\author{
Agung Ramadhanu \\ Program Studi Sistem Informasi \\ Universitas Putra Indonesia "YPTK" Padang \\ E-mail : agung_ramadhanu@upiyptk.ac.id
}

\begin{abstract}
Abstrak
Kanker mulut adalah kanker yang tumbuh dan berkembang di dalam mulut. Misalnya pada bibir, lidah, gusi, dinding mulut, serta langit-langit mulut. Kanker ini dapat menyebar secara langsung ke jaringan-jaringan di sekitar mulut atau melalui kelenjar getah bening. Karena masih banyak orang yang tidak mengetahui gejala-gejala pada kanker mulut. Maka salah satu teknik dalam mendiagnosis penyakit kanker mulut ini adalah sistem pakar. Maka dari itu penelitian ini bertujuan menyusun sebuah sistem pakar yang digunakan untuk diagnosa awal penyakit kanker mulut berdasarkan gejala yang dirasakan.pasien. Sistem akan menampilkan hasil penyakit dari gejala yang dialami pasien. Metode inferensi yang digunakan untuk mendapatkan konklusi yaitu penalaran maju (forward chaining).
\end{abstract}

Kata Kunci : Kanker Mulut, Sistem Pakar, Forwar Chaining

\section{Pendahuluan}

Kanker merupakan penyakit seluler yang ditandai dengan ciri adanya sifat pertumbuhan yang tidak terkendali diikuti proses invasi ke jaringan dan penyebaran atau metastasis ke bagian organ tubuh yang lain.1 Hampir semua kasus kanker disebabkan oleh mutasi atau aktivasi abnormal gen selular yang mengendalikan pertumbuhan sel dan mitosis sel. Gen abnormal disebut onkogen. Di dalam semua sel ditemukan antionkogen yang menekan aktivasi dari onkogen tertentu. Inaktivasi dari antionkogen dapat memungkinkan aktivasi dari onkogen dan mengarah kepada kanker. Hanya sejumlah kecil dari sel yang bermutasi mengarah pada kanker. Namun kemungkinan mutasi dapat berkali-kali lipat bila seseorang terpapar dengan radiasi ionisasi (sinar-X, sinar gamma, bahan radioaktif, sinar ultraviolet), bahan kimia seperti pewarna aniline dan asap rokok, bahan iritan fisik, herediter, dan virus.2 Daerah rongga mulut merupakan satu dari sepuluh lokasi tubuh yang paling sering terserang kanker. Kanker mulut menempati peringkat ketiga sesudah kanker lambung dan leher rahim. Ada beberapa jenis kanker rongga mulut, namun jenis yang paling tinggi (90\%) merupakan karsinoma sel skuamosa.3 Berdasarkan uraian di atas, untuk memecahkan masalah karsinoma sel skuamosa perlu diketahui diagnosis dan terapi yang tepat dalam penyembuhannya.

\section{Metodologi Penelitian}

Dalam penelitian ini, metode yang dilakukan, adalah melakukan wawancara di Klinik drg. Hengkie Marlie yang beralamatkan di Jl. Pondok No. 5d, Kp. Pd., Padang Bar., Kota Padang Sumatera Barat 25134 dengan dokter yang Drg. Hengkie Marlie Sp. Periodonsia. 
DOI: https://doi.org/10.47233/jteksis.v1i2.53

\subsection{Bahan Penelitian}

Bahan yang digunakan untuk penelitian ini adalah data-data dari dalam buku "Atlas Penyakit Mukosa Mulut" oleh( J.J PINBORG, 2016), serta data dari drg. Hengkie Marlie Serta buku-buku dan sumber lain yang menunjang pembuatan Perancanggan aplikasi sistem pakar menggunakan bahasa pemrograman Visual Basic 2017 dengan metode Forward Chaining dalam upaya mendiagnosis dini penyakit Kanker Mulut.

\subsection{Teknik Pengumpulan Data}

Adapun teknik pengumpulan data yang digunakan untuk penelitian sistem pakar diagnosis penyakit Kanker Mulut dengan bahasa pemrograman Visual Basic 2017 dengan metode Forward Chaining adalah sebagai berikut:

\subsubsection{Studi Pustaka}

Dalam penelitian ini, dilakukan pencarian dan pembelajaran dari berbagai macam sumber pustaka. Di antaranya data program di Klinik drg. Hengkie Marlie informasi dari dokter mengenai penanganan penyakit Kanker Mulut, buku-buku, jurnal, dan website yang berkaitan dengan perancangan sistem pakar menggunakan bahasa pemrograman Visual Basic 2017 dengan metode Forward Chaining dalam upaya mendiagnosis dini penyakit Kanker Mulut

\subsubsection{Wawancara}

Dalam pengembangan sistem pakar, dilakukan tanya jawab secara langsung kepada dokter untuk mendapatkan informasi yang dibutuhkan dalam proses perancangan sistem pakar dengan bahasa pemrograman Visual Basic 2017 dengan metode Forward Chaining dalam upaya mendiagnosis dini penyakit Kanker Mulut.

\subsection{Sistem Pakar}

Sistem pakar merupakan cabang dari AI (Artificial Inteligent) yang membuat ekstensi untuk spesialisasi pengetahuan guna memecahkan suatu permasalahan pada Human Expert. Human Expert merupakan seseorang ahli dalam suatu bidang ilmu pengetahuan tertentu, berarti expert memiliki suatu permasalahan yang tidak dapat dipecahkan oleh orang lain secara efisien.

\subsubsection{Forward Chaining}

Forward Chaining merupakan fakta untuk mendapatkan kesimpulan (conclusion) dari fakta tersebut. Penalaran ini berdasarkan fakta yang ada (data driven), metode ini adalah kebalikan metode Backward Chaining, dimana metode ini dijalankan dengan mengumpulkan fakta-fakta yang ada untuk menarik kesimpulan. Dengan kata lain, prosesnya dimulai dari facts (fakta-fakta yang ada) melalui proses interface fact (penalaran fakta-fakta) menuju suatu goal (suatu tujuan). Metode ini juga disebut menggunakan aturan IF-THEN dimana premise (IF) menuju conclusion (THEN) atau dapat juga dituliskan sebagai berikut:

\section{THEN (konklusi)}

Ada dua pendapat mengenai pelaksanaan metode ini. Pertama dengan cara membawa seluruh data yang didapat ke sistem pakar. Kedua dengan membawa bagian-bagian penting saja dari data yang didapat ke sistem pakar. Cara pertama lebih baik digunakan jika sistem pakar terhubung dengan proses otomatis dan penerima seluruh data dari database. Cara kedua menghemat waktu serta biaya dengan mengurangi data dan mengambil data yang dianggap perlu. Sebagai contoh, seperti kasus pada kedua metode di atas, maka berdasarkan metode ini langahlangkah yang diambil: 


\section{$\mathrm{R} 1$ : IF A and C, THEN B \\ R2 : IF D and C, THEN F \\ R3 : IF B and E, THEN F \\ R4 : IF B, THEN C \\ R5 : IF F, THEN G}

Kedua jenis strategi ini akan mengarah pada suatu kesimpulan. Namun, efisiensinya tergantung dari kondisi masalah yang dihadapi, jika suatu masalah memiliki premis jumlahnya lebih sedikit dibanding conclusion, maka strategi yang akan ditawarkan Backward Chaining.

\subsection{Perangkat Perancangan Sistem}

\subsubsection{Basis Data (Database)}

Basis data atau database adalah kumpulan data yang disimpan secara sistematik di dalam komputer. Basisdata juga dapat diolah atau dimanipulasi menggunakan perangkat lunak atau program aplikasi untuk menghasilkan suatu informasi. Pendefinisian basis data meliputi spesifikasi berupa tipe data, struktur data, dan juga batasan-batasan data yang akan disimpan

\subsubsection{Tabel Relasi}

Tabel relasi merupakan hubungan yang terjadi pada suatu tabel dengan tabel lain, yang berfungsi untuk mengatur operasi suatu database. Hubungan yang dibentuk dapat mencangkup tiga macam hubungan, yaitu :

1. One-To-One (1-1)

2. One- to-Many (1-N)

3. Many-To-Many (N-M)

\subsubsection{Aliran Sistem Informasi}

Menerangkan alur activity untuk melakukan diagnosa penyakit. Pertama user harus login dengan memasukkan username dan password, jika berhasil informasi akan disimpan di database. Jika berhasil sistem akan menampilkan menampilkan menu program. User akan memilih menginputkan gejala pasien pada sistem tersebut. Setelah menginputkan gejala, sistem akan mengolah gejala yang telah diinputkan user sebelumnya dan mengeluarkan output berupa hasil diagnosa penyakit yang diderita oleh user.

\subsubsection{Entity Relationship Diagram (ERD)}

Entity Relationship Diagram (ERD) merupakan gambaran bentuk hubungan antara filefile yang ada, dimana entity adalah suatu kesatuan atau kesimpulan data yang memiliki karakteristik yang sama. Entity biasa berupa orang, tempat, benda, peristiwa atau konsep yang memberikan atau yang mengandung suatu informasi. Berikut symbol-simbol yang terdapat pada ERD

\section{Analisa dan Perancangan}

\subsection{Analisa}

Pada dasarnya kegiatan yang dilakukan pada tahap analisis ini ada dua bagian, yaitu tahap survey pengumpulan data dan analisis terstruktur yang secara garis besar untuk memperoleh pengertian dari permasalahan-permasalahan, efisiensi dan pertimbanganpertimbangan yang mengarah ke pengembangan sistem. Memperkirakan kendala-kendala yang 
Vol. 1 No. 2 Juli 2019

DOI: https://doi.org/10.47233/jteksis.v1i2.53

akan dihadapi dalam pengembangan sistem tersebut dan menentukan solusi-solusi alternative pendahuluan.

Analisa dan perancangan bertujuan untuk membentuk optimasi dari aplikasi yang akan kita bangun dengan mempertimbangkan faktor-faktor permasalahan kebutuhan yang ada dalam sistem. Upaya yang dapat dilakukan adalah dengan mencari kombinasi perangkat lunak dan teknologi yang tepat sehingga dapat menghasilkan hasil yang tepat dan mudah diimplementasikan.

\subsection{Gejala Penyakit Kanker Mulut}

Data-data dasar yang telah didapatkan digunakan dalam operasional konsultasi dan sebagai bahan untuk merepresentasikan pengetahuan. Dalam sistem pakar untuk mendiagnosis gejala - gejala penyakit Kanker Mulut pengetahuan direpresentasikan dengan menggunakan kaidah produksi.

Secara default sistem ini memiliki rule diagnosis penyakit yang nantinya masih bisa ditambahkan oleh pakar. Daftar Rule (aturan) diagnosis pada system ini ditunjukkan pada table berikut:

Tabel 1 Data Penyakit

\begin{tabular}{|c|c|c|}
\hline Kode Penyakit & Nama Penyakit & Keterangan \\
\hline P001 & Karsinoma pada bibir(tepi merah bibir) & $\begin{array}{ll}\text { - } & \text { Kebiasaan merokok dan } \\
\text { menghisap pipa } \\
\text { - } \\
\text { Terlihat terutama } \\
\text { diantara pekerja yang } \\
\text { bekerja di udara terbuka }\end{array}$ \\
\hline $\mathrm{P} 002$ & Karsinoma pada pinggir lidah & $\begin{array}{ll}\text { - } & \text { Lebih banyak menyerang } \\
\text { laki-laki } \\
\text { - } \\
\text { Bisa disebabkan karena } \\
\text { gigi tiruan }\end{array}$ \\
\hline P003 & Karsinoma pada dasar mulut & $\begin{array}{l}\text { Menyerang orang pada } \\
\text { usia pertengahan dan } \\
\text { usia lanjut dengan } \\
\text { pervalensi tertinggi pada } \\
\text { dekade ketujuh }\end{array}$ \\
\hline P004 & Karsinoma pada komisura bibir & 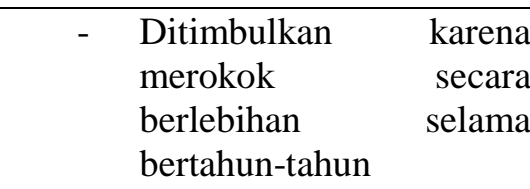 \\
\hline
\end{tabular}


DOI: https://doi.org/10.47233/jteksis.v1i2.53

\begin{tabular}{|c|c|c|}
\hline P005 & Karsinoma verukosa pada mukosa pipi & 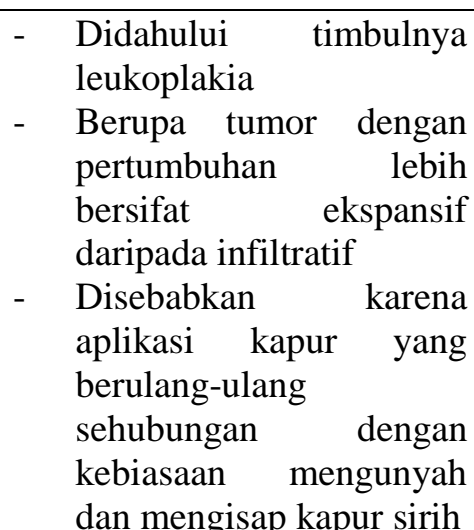 \\
\hline
\end{tabular}

Masalah yang dibahas dalam penelitian ini adalah mengenai penyakit Kanker Mulut. Setelah melakukan wawancara dengan pakar, sehingga mendapatkan kejelasan tentang penyakit tersebut.

Tabel 2 Data Gejala Penyakit

\begin{tabular}{|c|c|c|}
\hline No & Kode Gejala & Gejala \\
\hline 1. & G001 & $\begin{array}{l}\text { Peradangan kronis yang terjadi pada usus besar (kolon) dan } \\
\text { rektum. }\end{array}$ \\
\hline 2. & G002 & Saat diraba pada pinggiran tumor terasa keras. \\
\hline 3. & G003 & Adanya kerak atau keropeng pada tepi merah bibir \\
\hline 4. & G004 & Adanya penebalan atau adanya bercak putih pada mukosa bibir. \\
\hline 5. & G005 & Adanya ruam berwarna merah(erythroplakia). \\
\hline 6. & G006 & Adanya luka yang muncul pada bagian bawah lidah atau gusi \\
\hline 7. & G007 & $\begin{array}{l}\text { Adanya bercak mirip luka yang cekung di bagian tengah dan } \\
\text { disertai rasa sakit }\end{array}$ \\
\hline 8. & G008 & Rasa sakit pada tenggorokan \\
\hline 9. & G009 & $\begin{array}{l}\text { Lidah terasa nyeri berkepanjangan yang biasanya sampai terasa } \\
\text { pada rahang }\end{array}$ \\
\hline 10. & G010 & Lidah mati rasa dan sulit digerakkan \\
\hline 11. & G011 & $\begin{array}{l}\text { Dasar Tukak berwarna merah kelabu, lemas menampakkan } \\
\text { permukaann butiran kecil }\end{array}$ \\
\hline 12. & G012 & Terdapat Hifa kandida \\
\hline 13. & G013 & $\begin{array}{l}\text { Gambaran bercak putih dengan latar belakang berwarna merah } \\
\text { memberi kesan bintik }\end{array}$ \\
\hline 14. & G014 & Terdapat bercak atau plak berwarna merah terang \\
\hline 15. & G015 & Tumor terletak pada mukosa pipi \\
\hline 16. & G016 & Tumor pada mulanya relatif lunak dan berbatas jelas \\
\hline 17. & G017 & Tumor yang awalnya lunak kemudian menjadi kuat dan lebih keras \\
\hline 18. & G018 & $\begin{array}{l}\text { Terletak pada duapertiga anterior dan massa yang timbul tak terasa } \\
\text { sakit }\end{array}$ \\
\hline 19. & G019 & $\begin{array}{l}\text { Terletak pada sepertiga posterior dan rasa sakit yang dialami } \\
\text { dihubungkan dengan sakit tenggorokan }\end{array}$ \\
\hline
\end{tabular}

Berikut ini merupakan data-data gejala dari setiap penyakit yang di dapat dari hasil wawancara langsung dengan pakar yang memiliki kompetensi di bidangnya 
Tabel 3 Gejala dari Masing-Masing Penyakit

\begin{tabular}{|c|c|c|c|c|c|c|}
\hline \multirow{2}{*}{ ID Gejala } & \multirow{2}{*}{ Nama Gejala } & \multicolumn{5}{|c|}{ ID Penyakit } \\
\hline & & P001 & P002 & P003 & P004 & P005 \\
\hline G001 & $\begin{array}{l}\text { Peradangan kronis yang terjadi } \\
\text { pada usus besar (kolon) dan } \\
\text { rektum. }\end{array}$ & V & & & & \\
\hline G002 & $\begin{array}{l}\text { Saat diraba pada pinggiran } \\
\text { tumor terasa keras. }\end{array}$ & V & & V & & \\
\hline G003 & $\begin{array}{l}\text { Adanya kerak atau keropeng } \\
\text { pada tepi merah bibir }\end{array}$ & V & & & & \\
\hline G004 & $\begin{array}{l}\text { Adanya penebalan atau adanya } \\
\text { bercak putih pada mukosa } \\
\text { bibir. }\end{array}$ & V & & & V & V \\
\hline G005 & $\begin{array}{l}\text { Adanya ruam berwarna } \\
\text { merah(erythroplakia). }\end{array}$ & V & & & & \\
\hline G006 & $\begin{array}{l}\text { Adanya luka yang muncul pada } \\
\text { bagian bawah lidah atau gusi }\end{array}$ & & V & & & \\
\hline G007 & $\begin{array}{l}\text { Adanya bercak mirip luka yang } \\
\text { cekung di bagian tengah dan } \\
\text { disertai rasa sakit }\end{array}$ & & $\mathrm{V}$ & & & \\
\hline G008 & Rasa sakit pada tenggorokan & & $\mathrm{V}$ & & & \\
\hline G009 & $\begin{array}{l}\text { Lidah terasa nyeri } \\
\text { berkepanjangan yang biasanya } \\
\text { sampai terasa pada rahang }\end{array}$ & & $\mathrm{V}$ & & & \\
\hline G010 & $\begin{array}{l}\text { Lidah mati rasa dan sulit } \\
\text { digerakkan }\end{array}$ & & $\mathrm{V}$ & & & \\
\hline G011 & $\begin{array}{l}\text { Dasar Tukak berwarna merah } \\
\text { kelabu, lemas menampakkan } \\
\text { permukaann butiran kecil }\end{array}$ & & & V & & \\
\hline G012 & Terdapat Hifa kandida & & & & $\mathrm{V}$ & \\
\hline G013 & $\begin{array}{l}\text { Gambaran bercak putih dengan } \\
\text { latar belakang berwarna merah } \\
\text { memberi kesan bintik }\end{array}$ & & & & V & \\
\hline
\end{tabular}


DOI: https://doi.org/10.47233/jteksis.v1i2.53

\begin{tabular}{|c|c|c|c|}
\hline G014 & $\begin{array}{l}\text { Terdapat bercak atau plak } \\
\text { berwarna merah terang }\end{array}$ & & V \\
\hline G015 & $\begin{array}{l}\text { Tumor terletak pada mukosa } \\
\text { pipi }\end{array}$ & & V \\
\hline G016 & $\begin{array}{l}\text { Tumor pada mulanya relatif } \\
\text { lunak dan berbatas jelas }\end{array}$ & & V \\
\hline G017 & $\begin{array}{l}\text { Tumor yang awalnya lunak } \\
\text { kemudian menjadi kuat dan } \\
\text { lebih keras }\end{array}$ & & $\mathrm{V}$ \\
\hline G018 & $\begin{array}{l}\text { Terletak pada duapertiga } \\
\text { anterior dan massa yang timbul } \\
\text { tak terasa sakit }\end{array}$ & V & \\
\hline G019 & $\begin{array}{l}\text { Terletak pada sepertiga } \\
\text { posterior dan rasa sakit yang } \\
\text { dialami dihubungkan dengan } \\
\text { sakit tenggorokan }\end{array}$ & V & \\
\hline
\end{tabular}

Proses rule didapatkan mengacu dari gejela-gejala yang berhubungan dengan penyakit, terdapatlah beberapa rule untuk pengetahuan mengenai penyakit Kanker Mulut, proses rule tersebut adalah sebagai berikut

Tabel 4 Basis Pengetahuan

\begin{tabular}{|c|l|}
\hline No & Aturan \\
\hline 1. & $\begin{array}{l}\text { IF Peradangan kronis yang terjadi pada usus besar (kolon) dan rektum.AND Saat diraba } \\
\text { pada pinggiran tumor terasa keras AND Adanya kerak atau keropeng pada tepi merah bibir } \\
\text { AND Adanya penebalan atau adanya bercak putih pada mukosa bibir AND Adanya ruam } \\
\text { berwarna merah(erythroplakia) THEN } \\
\text { Karsinoma pada bibir (tepi merah bibir) }\end{array}$ \\
\hline 2. & $\begin{array}{l}\text { IF Adanya luka yang muncul pada bagian bawah lidah atau gusi AND Adanya bercak } \\
\text { mirip luka yang cekung di bagian tengah dan disertai rasa sakit AND Rasa sakit pada } \\
\text { tenggorokan AND Lidah terasa nyeri berkepanjangan yang biasanya sampai terasa pada } \\
\text { rahang AND Lidah mati rasa dan sulit digerakkan AND Terletak pada duapertiga anterior } \\
\text { dan massa yang timbul tak terasa sakit AND Terletak pada sepertiga posterior dan rasa } \\
\text { sakit yang dialami dihubungkan dengan sakit tenggorokan } \\
\text { THEN Karsinoma pada pinggir lidah }\end{array}$ \\
\hline 3. & $\begin{array}{l}\text { IF Saat diraba pada pinggiran tumor terasa keras AND Dasar Tukak berwarna merah } \\
\text { kelabu, lemas menampakkan permukaann butiran kecil THEN Karsinoma pada dasar } \\
\text { mulut }\end{array}$ \\
\hline 4. & $\begin{array}{l}\text { IF Adanya penebalan atau adanya bercak putih pada mukosa bibir AND Terdapat Hifa } \\
\text { kandida AND Gambaran bercak putih dengan latar belakang berwarna merah memberi }\end{array}$ \\
\hline
\end{tabular}


Vol. 1 No. 2 Juli 2019

DOI: https://doi.org/10.47233/jteksis.v1i2.53

\begin{tabular}{|c|l|}
\hline & $\begin{array}{l}\text { kesan bintik THEN } \\
\text { Karsinoma pada komisura bibir }\end{array}$ \\
\hline 5. & $\begin{array}{l}\text { IF Adanya penebalan atau adanya bercak putih pada mukosa bibir AND Terdapat bercak } \\
\text { atau plak berwarna merah terang AND Tumor terletak pada mukosa pipi AND Tumor } \\
\text { pada mulanya relatif lunak dan berbatas jelas AND Tumor yang awalnya lunak kemudian } \\
\text { menjadi kuat dan lebih keras THEN Karsinoma verukosa pada mukosa pipi }\end{array}$ \\
\hline
\end{tabular}

\subsection{Perancangan Sistem}

\subsubsection{Aliran Sistem Informasi (ASI) Lama}

Dalam perancangan Aplikasi Sistem pengolahan data gejala pada Kanker Mulut. terlebih dahulu dikaji terhadap sistem yang lama, yang telah lama digunakan. Berikut ini merupakan prosedur yang terjadi :

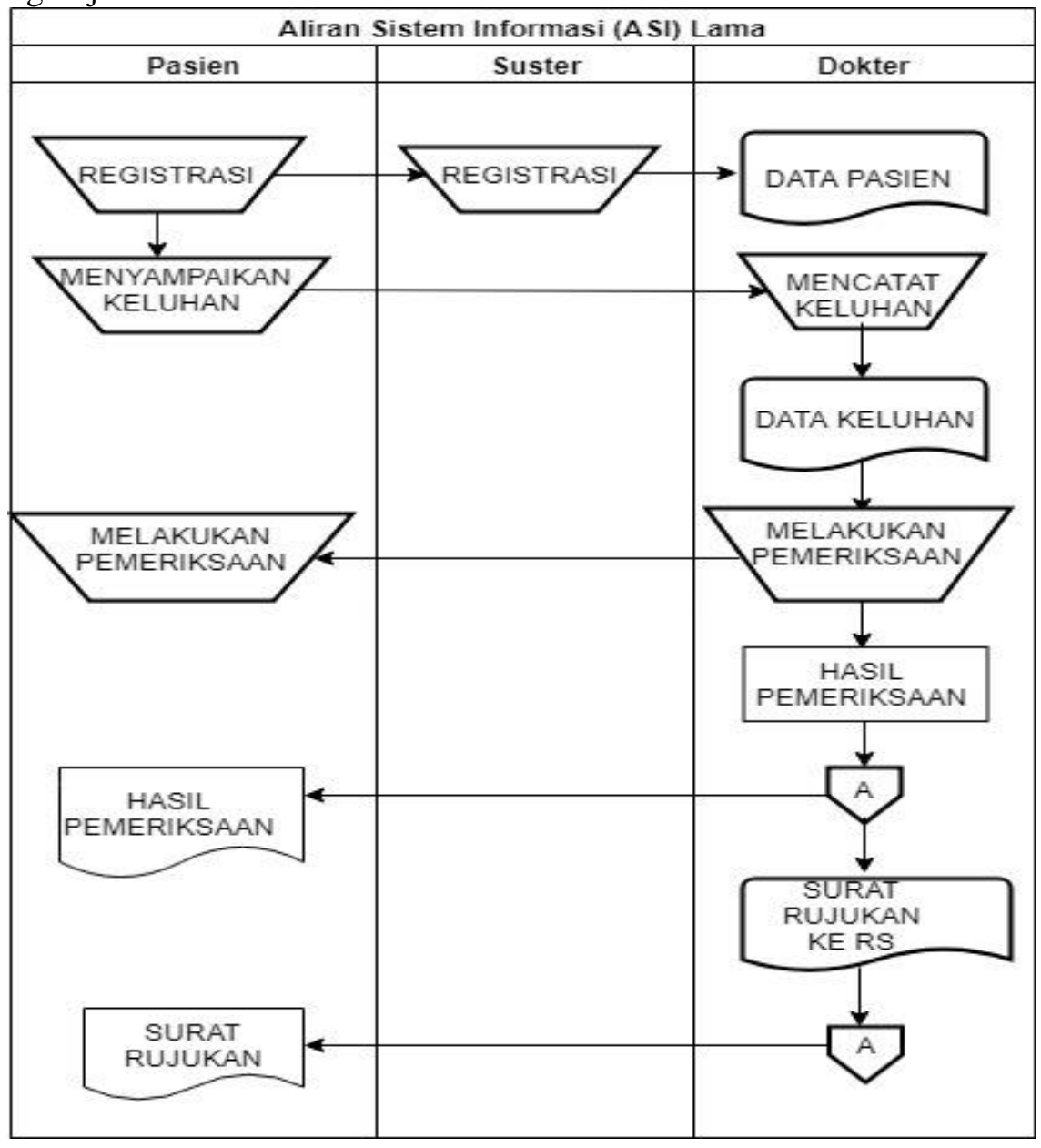

\subsubsection{Aliran Sistem Informasi (ASI) Baru}

Menerangkan alur activity untuk melakukan diagnosa penyakit. Pertama user harus login dengan memasukkan username dan password, jika berhasil informasi akan disimpan di database. Jika berhasil sistem akan menampilkan menampilkan menu program. User akan memilih menginputkan gejala pasien pada sistem tersebut. Setelah menginputkan gejala, sistem akan 
Vol. 1 No. 2 Juli 2019

DOI: https://doi.org/10.47233/jteksis.v1i2.53

mengolah gejala yang telah diinputkan user sebelumnya dan mengeluarkan output berupa hasil diagnosa penyakit yang diderita oleh user.

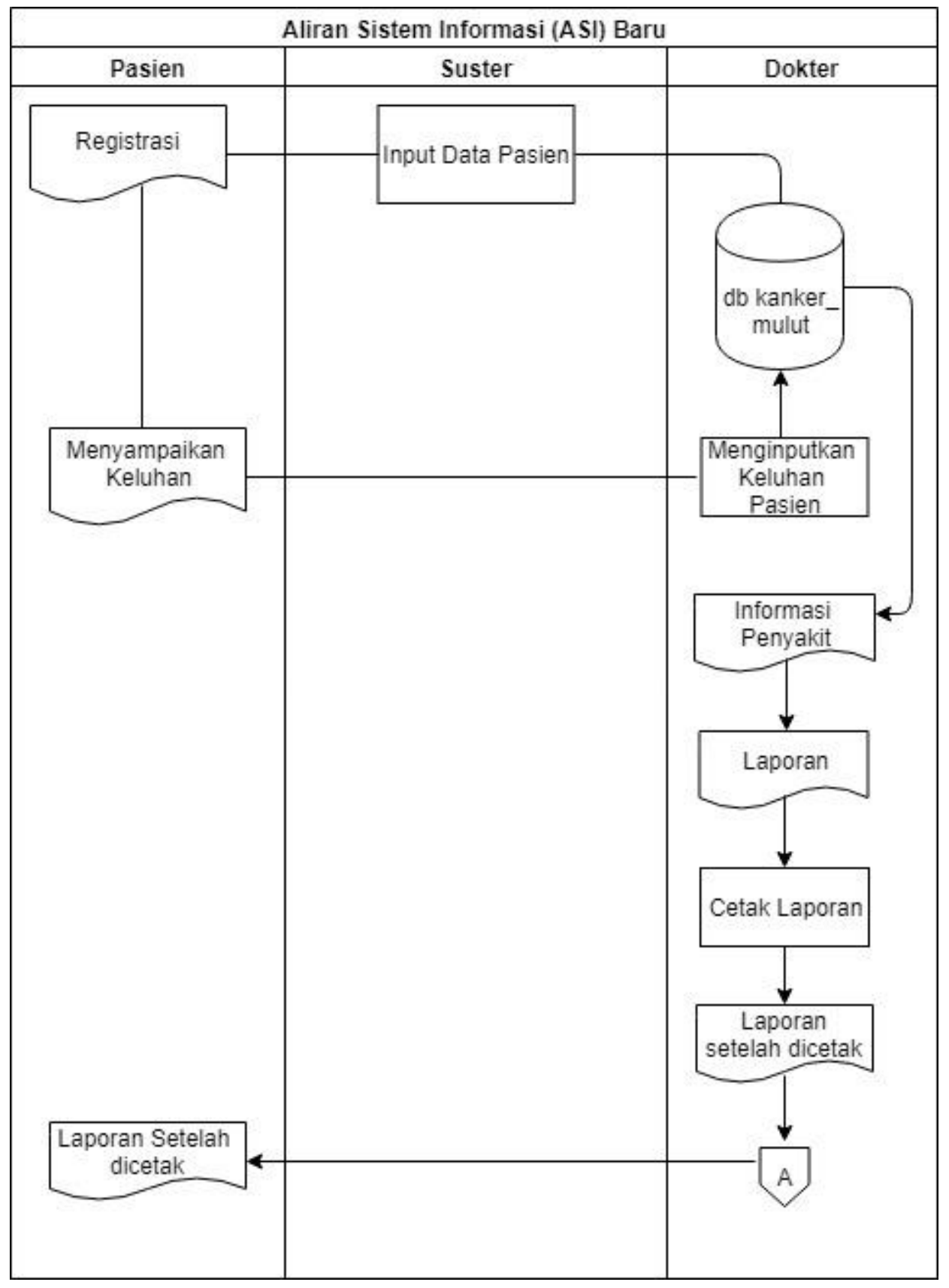


Vol. 1 No. 2 Juli 2019

DOI: https://doi.org/10.47233/jteksis.v1i2.53

\subsubsection{Entity Relationship Diagram}

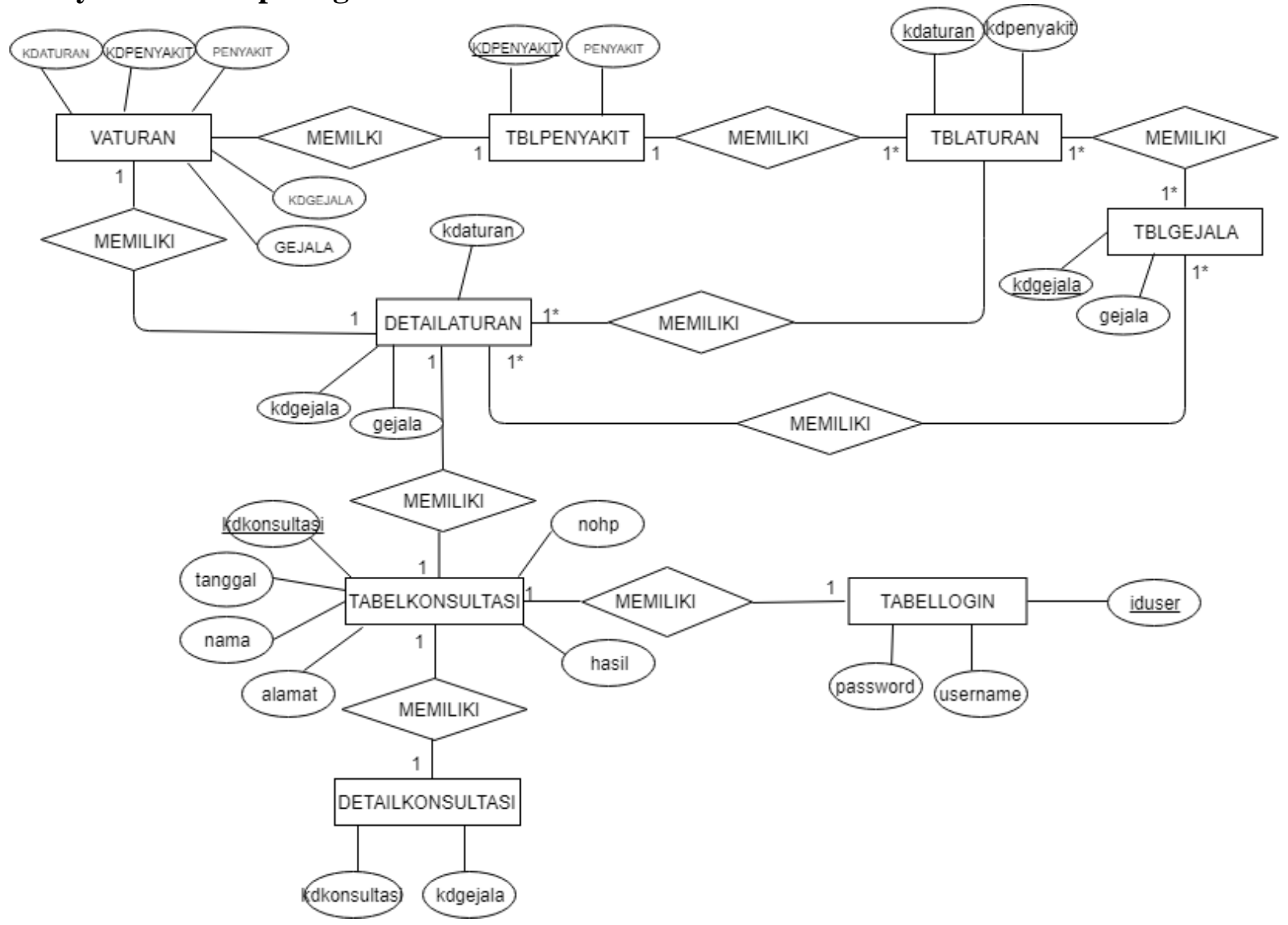

\subsection{Implementasi}

\section{Form Login}


Vol. 1 No. 2 Juli 2019

DOI: https://doi.org/10.47233/jteksis.v1i2.53

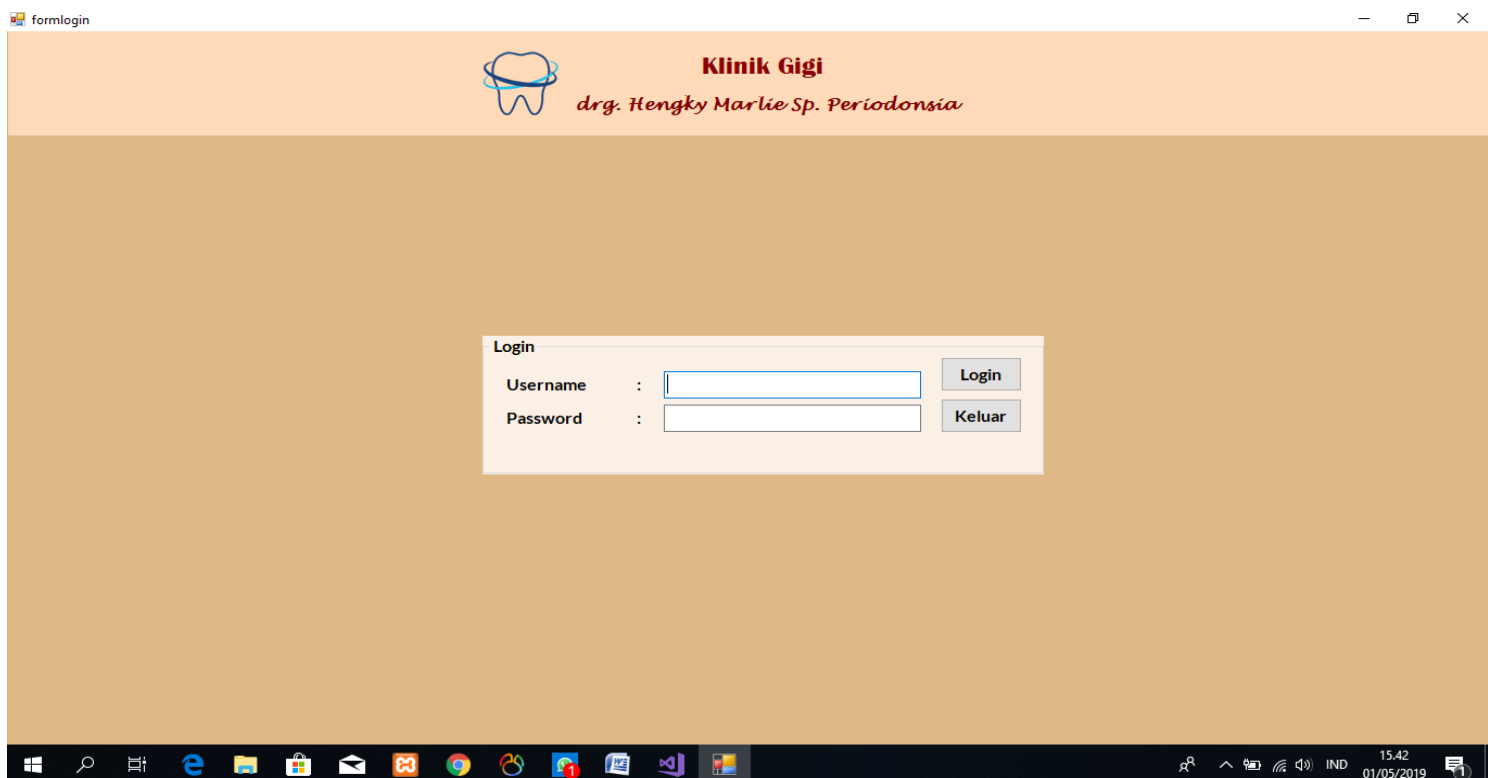

\section{Form Menu Utama}

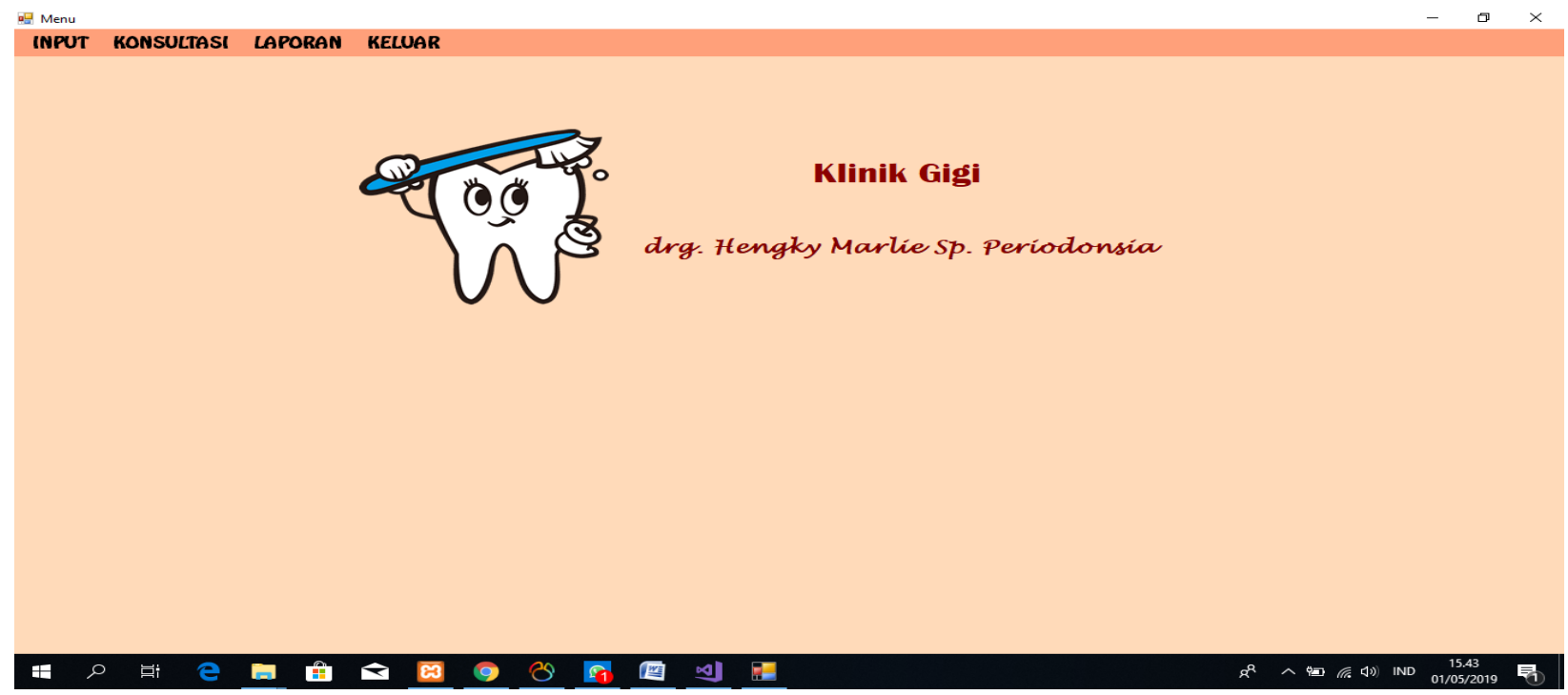

\section{Form Input Gejala}


Jurnal Teknologi Dan Sistem Informasi Bisnis

Vol. 1 No. 2 Juli 2019

DOI: https://doi.org/10.47233/jteksis.v1i2.53

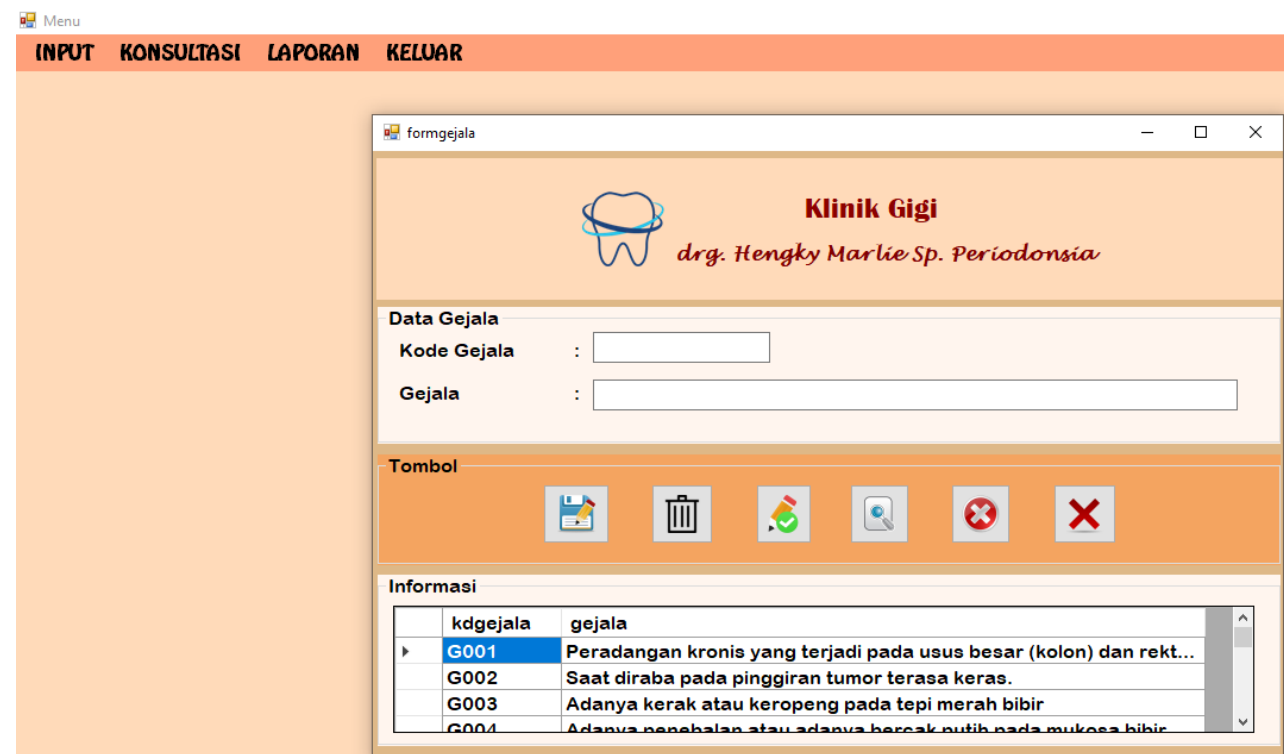

\# 0 苚

\section{Form Input Penyakit}


Jurnal Teknologi Dan Sistem Informasi Bisnis

Vol. 1 No. 2 Juli 2019

DOI: https://doi.org/10.47233/jteksis.v1i2.53

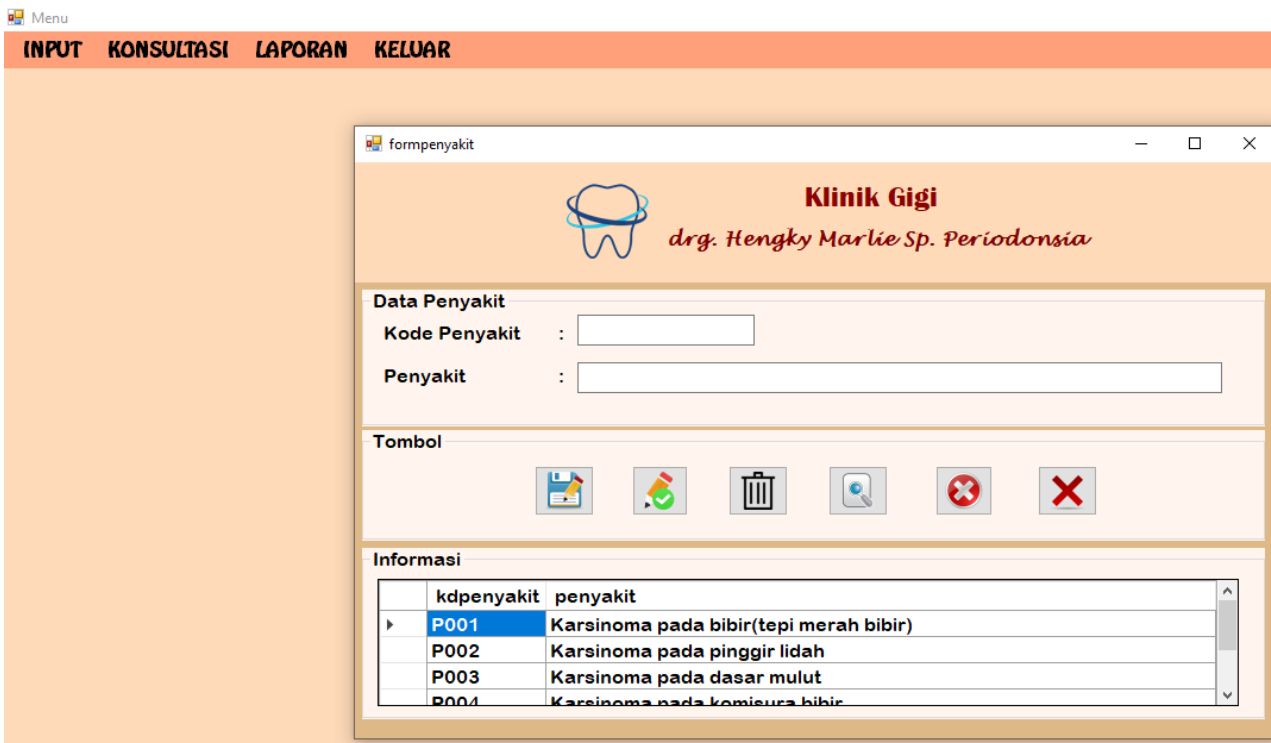

* 0 刑

\section{Form Input Aturan}

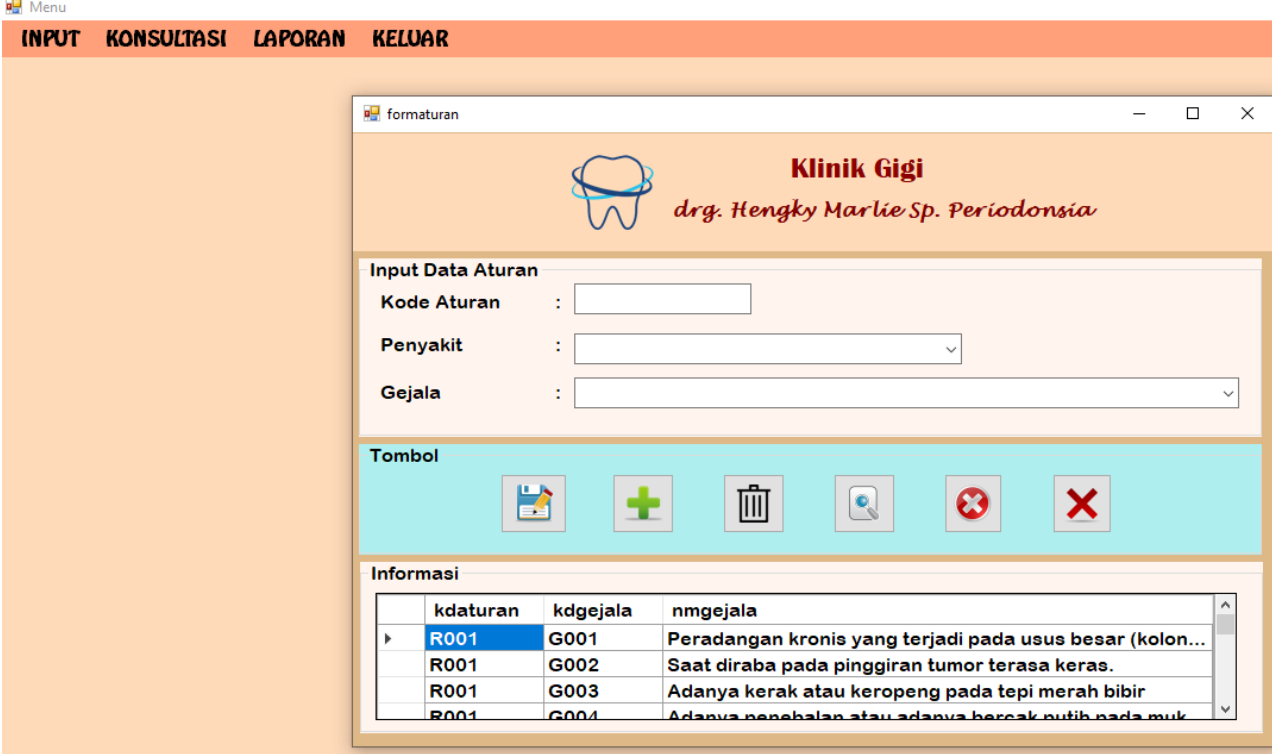

\# 0 苦

\section{Form Konsultasi}


Jurnal Teknologi Dan Sistem Informasi Bisnis

Vol. 1 No. 2 Juli 2019

DOI: https://doi.org/10.47233/jteksis.v1i2.53

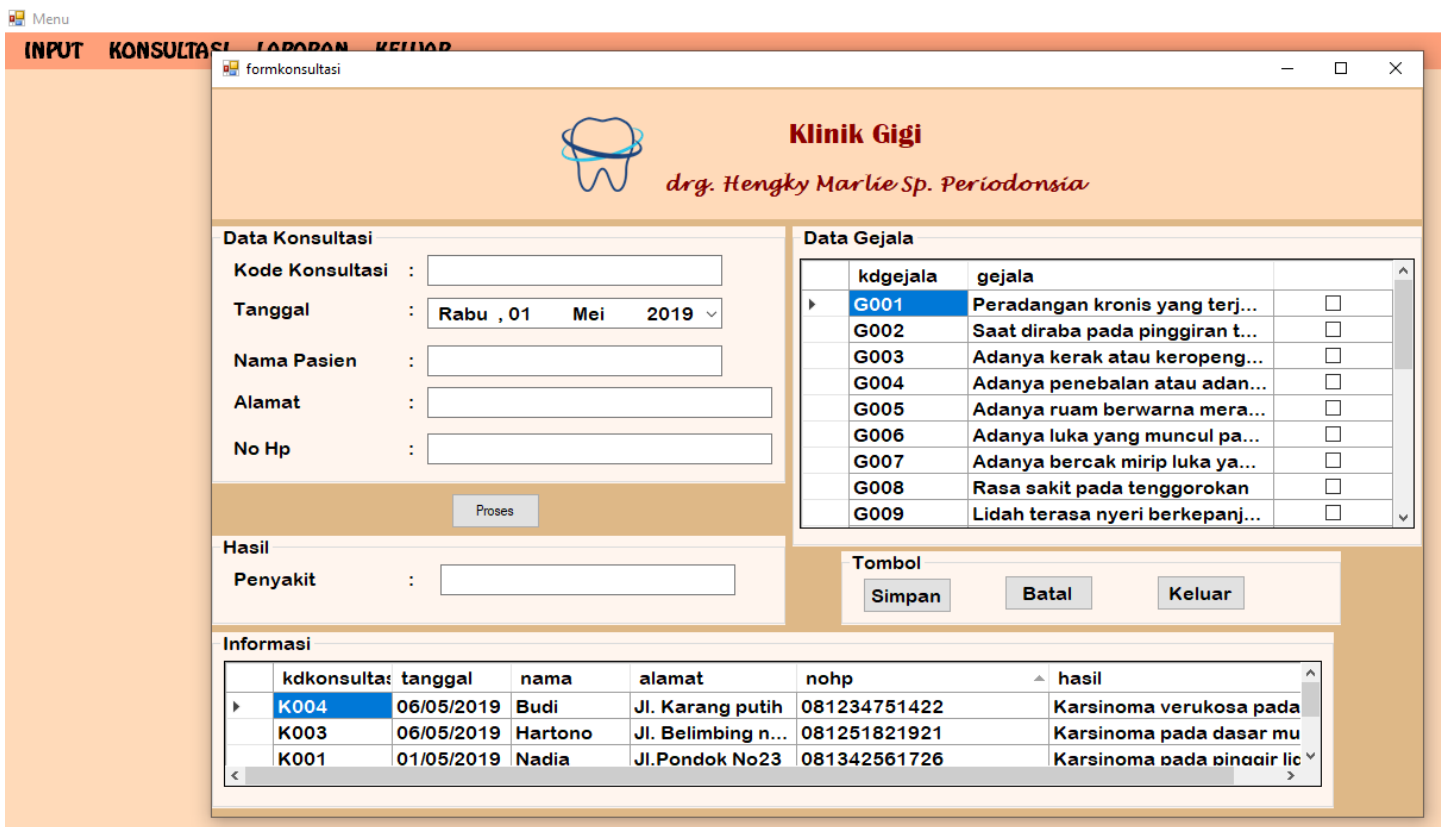

\#

\section{Form Laporan}

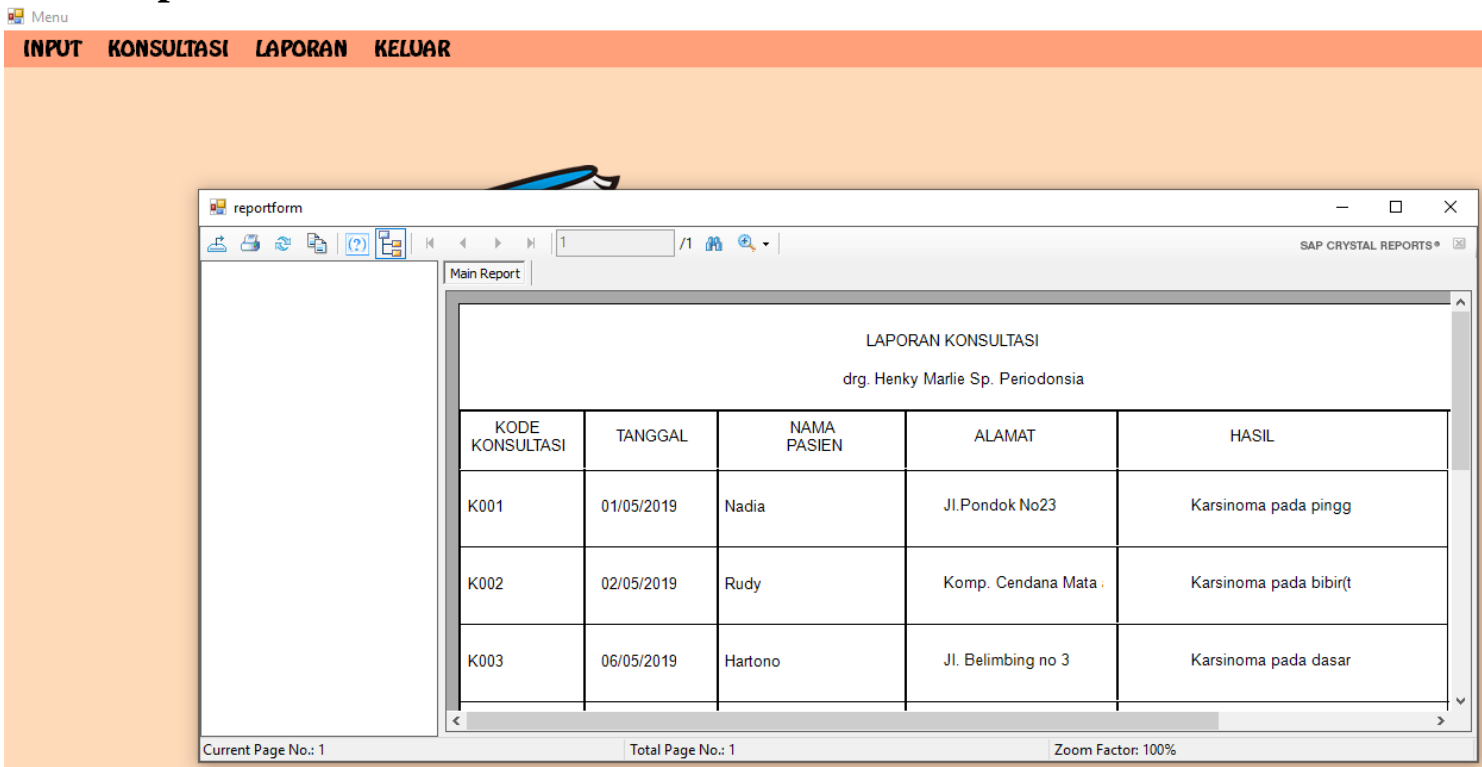

\section{Kesimpulan}


DOI: https://doi.org/10.47233/jteksis.v1i2.53

Berdasarkan uraian dari bab-bab sebelumnya, maka penulis dapat memberikan kesimpulan sebagai berikut :

1. Dalam prensentasi gejala penyakit kolestrol pada remaja memiliki 5 rule ( Aturan ) diagnosa yang selanjutnya dilakuakan basis pengetahuan untuk digunakan menentukan pasien menghidap penyakit Kanker Mulut atau tidak.

2. Penerapan Metode Forward Chaining dapat mempermudah dan memberikan hasil penyakit berdasarkan gejala yang dialami pasien

\section{Referensi}

[1] "Atlas Penyakit Mukosa Mulut” oleh( J.J PINBORG, 2016)

[2] T. Sutojo. 2011. Kecerdasan Buatan, Yogyakarta. Penerbit Graha Ilmu.

[3] Adhi Kusnadi. 2013. Perancangan Aplikasi Sistem Pakar Untuk Diagnosa Penyakit Pada Manusia. library.umn.ac.id/jurnal/.../cf1a586dead0f479bc5fb4add0331450.pdf.

[4] Afriosa Syawitri, Sarjon Defit, Gunadi Widi Nurcahyo. 2018. Diagnosis Penyakit Gigi dan Mulut Dengan Metode Forward Chaining. http://ejournal.uinsuska.ac.id/index.php/sitekin/article/view/6733/3843.

[5] Mulyani Fajrin, Dini Destiani. ISSN : 2302-7339 Vol. 12 No. 1 2015. Perancangan Sistem Pakar Diagnosis Penyakit Kanker Mulut.

[6] Sukarno Bahat Nauli, Anthoni Septian Anthoni. ISSN 2580-5495 Prosiding Seminar Nasional Inovasi Teknologi - SNITek 2017. Sistem Pakar Mendiagnosa Penyakit Gigi dan Mulut Dengan Menggunakan Metode Foward Chaining.

[7] Budi Kurniawan. 2011. Aplikasi Sistem Pakar Berbasis Web Untuk Diagnosa Penyakit Gigi dan Mulut. 